IRA-International Journal of Education \& Multidisciplinary Studies

ISSN 2455-2526; Vol.09, Issue 01 (October, 2017)

Pg. no. 8-19

Institute of Research Advances

http://research-advances.org/index.php/IJEMS

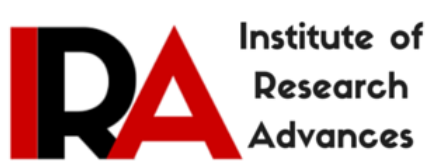

\title{
The Study of Peace Awareness among Undergraduate Students
}

\author{
Dr. Anjum Ahmed ${ }^{1 \#} \&$ Siam Iftekhar ${ }^{2}$ \\ ${ }^{1}$ Assistant Professor, Department Of Education, Aligarh Muslim University, Aligarh, India. \\ ${ }^{2}$ M.Ed. Student, Department Of Education, Aligarh Muslim University, Aligarh, India. \\ \# corresponding author. \\ Type of Review: Peer Reviewed. \\ DOI: http://dx.doi.org/10.21013/jems.v9.n1.p2
}

\section{How to cite this paper:}

Ahmed, A., Iftekhar, S. (2017). The Study of Peace Awareness among Undergraduate Students. IRA International Journal of Education and Multidisciplinary Studies (ISSN 2455-2526), 9(1), 8-19. doi: http://dx.doi.org/10.21013/jems.v9.n1.p2

(C) Institute of Research Advances.

\section{(cc) BY-NC}

This work is licensed under a Creative Commons Attribution-Non Commercial 4.0 International License subject to proper citation to the publication source of the work.

Disclaimer: The scholarly papers as reviewed and published by the Institute of Research Advances (IRA) are the views and opinions of their respective authors and are not the views or opinions of the IRA. The IRA disclaims of any harm or loss caused due to the published content to any party.

Institute of Research Advances is an institutional publisher member of Publishers Inter Linking Association Inc. (PILA-CrossRef), USA. The institute is an institutional signatory to the Budapest Open Access Initiative, Hungary advocating the open access of scientific and scholarly knowledge. The Institute is a registered content provider under Open Access Initiative Protocol for Metadata Harvesting (OAI-PMH).

The journal is indexed \& included in WorldCat Discovery Service (USA), CrossRef Metadata Search (USA), WorldCat (USA), OCLC (USA), Open J-Gate (India), EZB (Germany) Scilit (Switzerland), Airiti (China), Bielefeld Academic Search Engine (BASE) of Bielefeld University, Germany, PKP Index of Simon Fraser University, Canada. 


\begin{abstract}
The word peace can be defined well through three basic point inner peace (peace with self), social peace (means the social understanding, social adjustments and social relationships between the individuals who live in the society) and peace with nature (means to stay in harmony with nature, to obey the natural phenomena and not to disturb the natural dignity through environment and economic exploitation and stratification). Peace education is an umbrella term and can be difficult to define. In a very simple word, peace education give the learners the knowledge, skills, attitudes and values which are necessary to end violence and injustice in the society and promote a culture, inner, social peace within the individual. Peace education is an essential component of quality basic education. It is concerned with helping learners to develop an awareness of the process and skills that are necessary for achieving understanding, tolerance and goodwill in the world today. The present study aims to find out the awareness of peace education among the undergraduate students of the AMU, Aligarh. A sample of 300 undergraduate students was selected by using stratified random sampling. The results and implications of the findings are discussed in the paper.
\end{abstract}

Key words: peace education, peace awareness, social skills, understanding conflict, inner peace, emotional radar, human rights and peace with nature.

\title{
Introduction
}

We, human beings are the greatest creatures of God. We have a greater tendency to live together happily and perfectly. Also humans always try to be self-sufficient and self -reliant. Every individual wants to be happy. He wants to achieve a proper harmony in intrapersonal, interpersonal relation with himself and with others, to live happily. It is for this reason that man has a tendency to keep a distance from the violence, conflict and war, and experience serenity in his simple way of living. History has proved that men have used their intellectual abilities, communication ability to avoid violence, conflict and to established peace. Another way of analyzing is that history of human beings is the history of searching for peace. Peace has been talked, thought, taught and studied in many ways and in many aspects.

\section{Concept of peace}

In general sense, it means the absence of war, conflict. But in broader sense, peace means the harmony relationship between the individuals with himself, with others, and with nature.

Etymologically the word peace is a translation of the Hebrew word 'shalom', which, according to Jewish theology, comes from a Hebrew verb meaning 'to restore', which is also cognate with the Arabic 'salaam', has multiple other meanings in addition to peace, including justice, good health, safety, well-being, prosperity, equity, security, good fortune, and friendliness. Peace means being one with life itself, having no fear or bitterness. Peace therefore, is a state of mind.

\section{Concept of Peace Education}

In UNICEF, peace education is defined as "the process of promoting the knowledge, skills, attitudes and values needed to bring about behaviour change that will enable children, youth and adults to prevent conflict and violence, both overt and structural; to resolve conflict peacefully; and to create the conditions conducive to peace, whether at an interpersonal, intergroup, national or international level". According to this definition peace education is the way in which the society can be modified in a good manner to prevent conflict and to bring harmony in society. Peace education is both a philosophy and a process inclusive of skills, attitudes and knowledge to create a safe world, to build a sustainable environment and to bring social change (Harris \& Morrison, 2003).

Peace education should be a participatory process which aims at changing society's way of thinking and which promotes learning of peace. Education should be put on issues that may lead to conflict well such as gender studies, speaking the language of non-violence and creation of proper international relations. peace education is include all the duties, responsibilities of human toward making the society best for all and living in harmony with oneself, society and nature by cooperation, help, forgiveness, respect towards self and others and develop inner peace, man kindness. 


\section{Education for peace means}

$>\quad$ Examining and discussing our values and attitudes towards diversity, cultural differences, tolerance and human dignity and directing our efforts towards achieving fundamental changes within societies.

$>\quad$ Developing language and social interaction skills to promote peaceful relations among people, among nations and between human beings and the natural environment.

$>\quad$ Learning to solve problems and to think critically regarding issues of conflict and violence.

\section{Significance and Necessity of Peace Education}

Students are in many ways aware of their individual, environmental, social and political issues that affect their daily lives. Moreover, the disorder of the world around them is reflected in their experiences in the schools in many ways. Schooling simply intervenes in an ongoing educational process whereby they learn knowledge, skills and attitudes, which they will require to function as responsible members of their societies. What is interesting is the fact that the very skills that are needed to address the current inequalities are the same behaviours required to function in school/college settings. This means that the schools, colleges and other educational institutions can effectively become social arenas, where equality is visualized mostly. In order to achieve this goal, schools, colleges and boards of education must adopt curriculum and practices congruent with peace education.

In the developed countries the advancement of technology and better economic conditions and the status of being advanced have caused serious problems to institutions managers of developed nations also. Students carry weapons to school in their daily routine. Besides the general delinquencies, vandalism, habit of smoking, tobacco chewing and consuming alcohol, cases of drug injection are highlighted in research studies abroad. It would not be wrong to say that conditions are far worse in international schools.

For Galtung (1996), peace education is an essential part of in-class education; with the proper training, students can carry this training with them into their work, home and social lives. Galtung (1996) recognizes that teachers have a vital role in the initiation of this life-long learning. Given that teachers in today's society are now, more than ever, preparing students for multicultural living, the support of faculties of education, ministries of education and educational institutions of all statures must recognize and support this developing role (Galtung, 1996).

From the beginning of the development of systematic peace education, there has been discussion about whether it should be added as a separate program in the schools, or if the principles of peace education should be applied through the regular school subjects. Aspeslagh (1996) believed that the implementation of principles of peace education into the institutionalized educational system is a better approach, especially within the subjects encompassing the cultural heritage of the dominant society and the ethnic groups belonging to it. He wrote about the need to internationalize peace education in national curriculums; including within the curriculum the contributions of minority groups to literature, history, art, the general cultural heritage, and the development of the particular nation state, in hopes of creating a level of understanding and empathy between cultures.

Peace education training for pre-service teachers, which focuses on the demolition of racial discrimination the recognition of gender inequality and conflict resolution, will aid them when dealing with potential classroom clashes resulting from the differing cultural and ethnic views of students, teachers, administrators and parents.

In the past century, peace is also one of the widely studied fields in positive psychology following the introduction of theoretical explanations of peace and peace psychology (Fitz-Gibbon, 2010; Roffey, 2012). For example, Danesh (2006, p. 60) proposed the integrative theory of peace and described it as a "psychological, social, ethical and spiritual state with expressions at intrapersonal, interpersonal, intergroup and international areas of human life". The theory states peace attitudes are the outcome of human capacities for knowing, loving, and choosing. Similarly, Wagner, Rivera, and Watkins (1998) described peace as "an active structure based on the intimacy and cooperation between individuals and nations." According to Wagner et al. (1988), having a positive attitude towards peace means that one who has positive attitudes towards peace desires peace effectively, behaviourally and cognitively. Apart from these theoretical explanations, positive correlations have been found between peace attitudes and self-esteem (Eryilmaz, 2009), and the personality traits of conscientiousness, extraversion, and agreeableness (Eryilmaz, 2014), hope (Sari \& Kermen, 2015), and subjective well-being (Diener \& Tov; 2007, Sari \& Kermen; 2015b).

Another important aspect is that teacher education and schools are crucial in peace education initiatives (Bercaw and Stooksberry, 2004; Reardon, 2001; Ssenkumba, 2010). Schools are a major starting point in peace education activities because they carry the responsibility to help learners understand problems of war and peace in 
their communities and worldwide. Therefore, schools are a key element of the peace education processes and are important conduits for peace education initiatives. (Hantzopoulos, 2011)

It is true that successful peace education practices in schools are dependent on systematic teacher preparation (Bajaj, 2011; Bartlett, 2009; Wilson and Daniel, 2007). As pointed out by Baker, Martin and Pence (2008), for teachers to be effective in teaching peace, teacher education institutions have to introduce peace education in all their programmes. Teacher education in peace education was emphasised in this chapter cognisant that "teachers are responsible for the practical implementation of the curricula in schools" (Cardozo, 2008:22).

The necessity of peace education for college students are very broad and live changing. Peace education for them is itself a movement for social equality and justice for each issue. There are wide needs of peace educations for college students, some of them are listed below:

- Bringing about peace-orientation in individuals through education.

- To develop the social skills and outlook needed to live together in harmony.

- Reinforcing social justice, as envisaged in the Constitution.

- To propagate a secular culture among students.

- Peace education as a catalyst for activating a democratic culture.

- For promoting national integration through education.

- Education for peace as a lifestyle movement. Students can be made aware of the need to reform their lifestyles conducive to the integrity of creation and stability of society.

- Education for peace focused more on citizenship education. Thus the various challenges to national unity can be the focus thereafter.

- The main emphasis on promoting an attitude of respect for diversity and difference.

- To become aware of the various hindrances to unity among students.

- Peace education helps in understanding the logic, modes and expressions of violence.

- Peace education helps in acquire skills for an objective understanding of issues; and

- Peace education helps in developing a global perspective on peace.

- To make learners aware of the basis of conflict in their daily lives.

- To use classroom as a microcosm of a just world order, in which the global values of positive inter dependence, social justice and participation in decision making processes are learned and practiced.

- To prepare students to become good citizens with skills to promote peace and human dignity at all levels of interaction.

- To prevent continued cycles of violence, education must promote peace, tolerance and understanding to help create a better society for all.

- It would contribute in the development of healthy environment for promotion of the spirit of peace and total satisfaction.

- It would teach students to manage conflicts and show them the way to solve their day to day problems.

- It would impress upon students that they are the fountain source of peace, happiness and joy.

- It would make students realize that empowering women means educating and empowering every member of the family and the nation.

- It would channelize students' vital energy in the right direction.

- The exposure to the domain of peace would make students vibrant with the spirit of cherishing positive ideas.

\section{Delimitations}

The delimitations of the present study are as following:

$>\quad$ Due to paucity of time the sample taken for the study is only 300 .

$>\quad$ The present study is conducted only in AMU faculties' i.e. social sciences, science and arts.

$>\quad$ The sample is taken from Aligarh district only.

$>\quad$ The sample is taken from only undergraduate students.

\section{Objectives of the study}

The objectives formulated for the study are: 
1. To find out the significant difference in the mean scores of peace awareness between under graduate boys and girls.

2. To find out the significant difference in the mean scores of peace awareness between under graduate social sciences girls and arts girls.

3. To find out the significant difference in the mean scores of peace awareness between under graduate social sciences girls and sciences girls.

4. To find out the significant difference in the mean scores of peace awareness between under graduate arts girls and sciences girls.

5. To find out the significant difference in the mean scores of peace awareness between under graduate social sciences boys and arts boys.

6. To find out the significant difference in the mean scores of peace awareness between under graduate social sciences boys and sciences boys.

7. To find out the significant difference in the mean scores of peace awareness between under graduate arts boys and sciences boys.

\section{Hypotheses of the study}

The hypotheses formulated for the study are:

1. There will be no significance difference in the mean scores of peace awareness between undergraduate boys and girls.

2. There will be no significance difference in the mean scores of peace awareness between undergraduate social sciences girls and arts girls.

3. There will be no significance difference in the mean scores of peace awareness between undergraduate social sciences girls and science girls.

4. There will be no significance difference in the mean scores of peace awareness between undergraduate arts girls and science girls.

5. There will be no significance difference in the mean scores of peace awareness between undergraduate social sciences boys and arts boys.

6. There will be no significance difference in the mean scores of peace awareness between undergraduate social sciences boys and science boys.

7. There will be no significance difference in the mean scores of peace awareness between undergraduate arts boys and science boys.

\section{Methodology}

The research is a descriptive type of research. It is based on the survey on the samples opinion that was made through the collecting of data. The questionnaire method is used as the tool for the research.

\section{Population for study}

The populations for this study will the undergraduate students from Aligarh Muslim University at Aligarh.

\section{Sample}

For this research a total number of 300 undergraduate students were considered from Aligarh Muslim University. The procedure used for sampling was stratified random sampling.

\section{Tool used in the study}

The scale 'Peace Awareness Scale' is self-constructed with six dimensions namely: Dimension 1- Social Skill (SS): Social skill is any skill facilitating interaction and communication with others. Social rules and relations are created, communicated, and changed in verbal and nonverbal ways.

Dimension 2- Understanding Conflict (UC):Conflict is defined as a clash between individuals arising out of a difference in thought process, attitudes, understanding, interests, requirements and even sometimes perceptions. Understanding Conflict involves the steps undertaken to know the causes of conflict, prevent the conflict at the right time and also helps to resolve it in an effective and smooth manner. 
Dimension 3- Inner Peace (IP):Inner peace is living in harmony with oneself (positive attitudes, beliefs and skills of dealing with the conflicts and issues).

Dimension 4- Emotional Radar (ER): Emotional intelligence (EI) or emotional quotient (EQ) is the capacity of individuals to recognize their own, and other people's emotions, to discriminate between different feelings and label them appropriately, and to use emotional information to guide thinking and behavior. It is just like radar, a measuring instrument, which is used to detect the incoming objects within the specific area or radius. An emotional intelligent person would be very well aware of its emotions and would know exactly how the others are feeling and will respond accordingly.

Dimension 5- Human Rights (HR):The term Human Rights is defined as every individual is entitled to live with self-respect and to be under protection in civil, political, economic, social and cultural fields.

Dimension 6- Peace with Nature (PN): Environmental protection is a practice of protecting the natural environment on individual, organizational or governmental levels, for the benefit of both the environment and humans. In other words it means living in harmony with natural environment.

To be a valid test, it must be reliable. A highly reliable test is always a valid measure of some function. Thus, if a test has a reliability coefficient of 0.724 , its index of reliability is $\sqrt{ } 0.724$ or $\mathbf{0 . 8 5}$. This means that the test correlates $\mathbf{0 . 8 5}$ with true measures of itself -these true measures constituting the criterion (Garrett, 2009; 360).

The Cronbach's Alpha coefficient accessing the internal consistency of the instrument for the total scale found to be $\mathbf{0 . 7 2 4}$, indicating an acceptable degree of internal consistency for group analysis. Thus the scale is reliable.

\section{The data has been analyzed as per the objectives of the study}

Objective 1: To find out the significant difference in the mean scores of peace awareness between undergraduate boys and girls.

Hypothesis $\left(\mathrm{H}_{01}\right)$ : There will be no significance difference in the mean scores of peace awareness between undergraduate boys and girls.

Table 1 Statistical values of boys and girls undergraduate students.

\begin{tabular}{|l|l|l|l|l|l|l|l|l|}
\hline Sample & $\mathbf{N}$ & Mean & S.D. & df & $\begin{array}{l}\text { t- value } \\
\text { calculated }\end{array}$ & $\begin{array}{l}\text { Tabulated } \\
\text { t-value }\end{array}$ & L.O.S. & $\begin{array}{l}\mathbf{H}_{\mathbf{0}} \\
(\mathbf{A} / \mathbf{R})\end{array}$ \\
\hline Boys & 150 & 348.45 & 26.24 & 298 & 0.445 & 1.96 & 0.01 & Accepted \\
\cline { 1 - 4 } & & & & & & 2.58 & 0.05 & \\
\hline
\end{tabular}

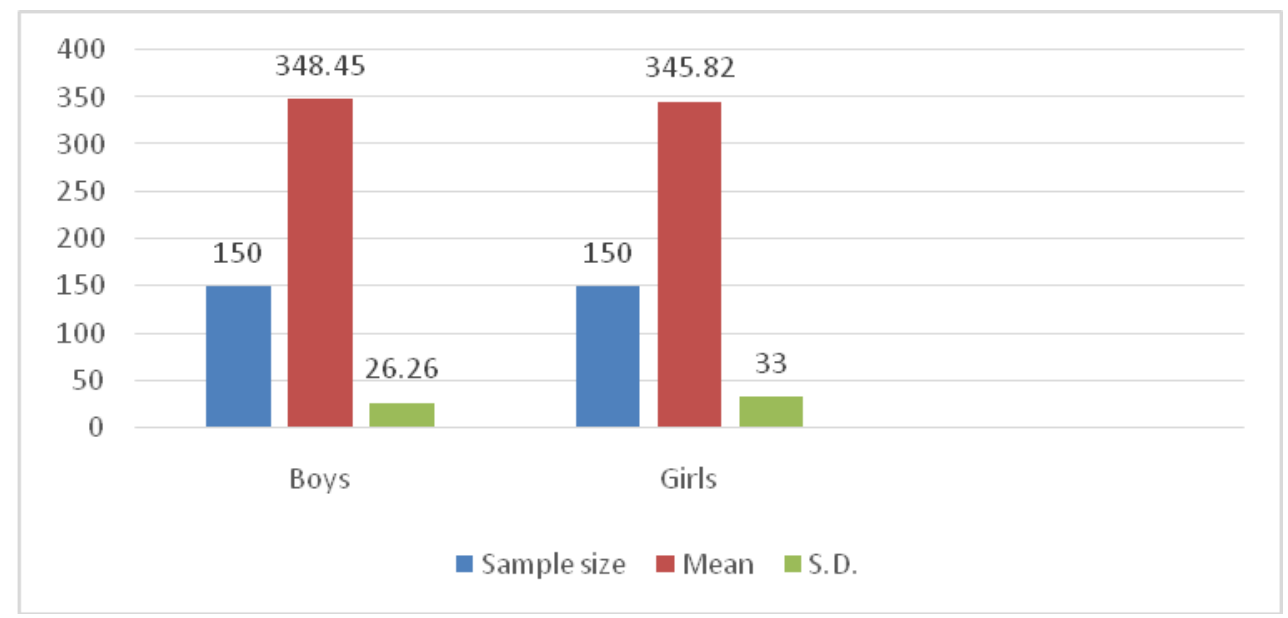

Graph 1 Statistical values of boys and girls undergraduate students. 
Interpretation: It is depicted from the above table and graph that the calculated value of ' $t$ ' $(0.445)$ is less than the tabulated value of ' $t$ ' (1.96 \& 2.58) at both the level of significance $(0.05 \& 0.01)$ respectively. So the null hypothesis is accepted and it shows that there is no significant difference in the mean scores of peace awareness between undergraduate boys and girls. It further shows that boys have more peace awareness than the girls because the mean score of boys (348.45) is higher than the girls (345.82).

Objective 2: To find out the significant difference in the mean scores of peace awareness between under graduate social sciences girls and arts girls.

\section{Hypothesis}

$\left(\mathrm{H}_{02}\right)$ : There will be no significance difference in the mean scores of peace awareness between undergraduate social sciences girls and arts girls.

Table 2 Statistical values of social science girls and arts girls undergraduate students.

\begin{tabular}{|l|l|l|l|l|l|l|l|l|}
\hline Sample & $\mathbf{N}$ & Mean & S.D. & df & $\begin{array}{l}\text { t- value } \\
\text { calculated }\end{array}$ & $\begin{array}{l}\text { Tabulated } \\
\text { t-value }\end{array}$ & L.O.S. & $\begin{array}{l}\mathbf{H}_{\mathbf{0}} \\
(\mathrm{A} / \mathbf{R})\end{array}$ \\
\hline $\begin{array}{l}\text { Social } \\
\text { science }\end{array}$ & 50 & 344.70 & 42.89 & 98 & 0.797 & 1.96 & 0.01 & Accepted \\
\cline { 1 - 5 } Arts girls & 50 & 346.58 & 28.68 & & & 2.58 & 0.05 & \\
\hline
\end{tabular}

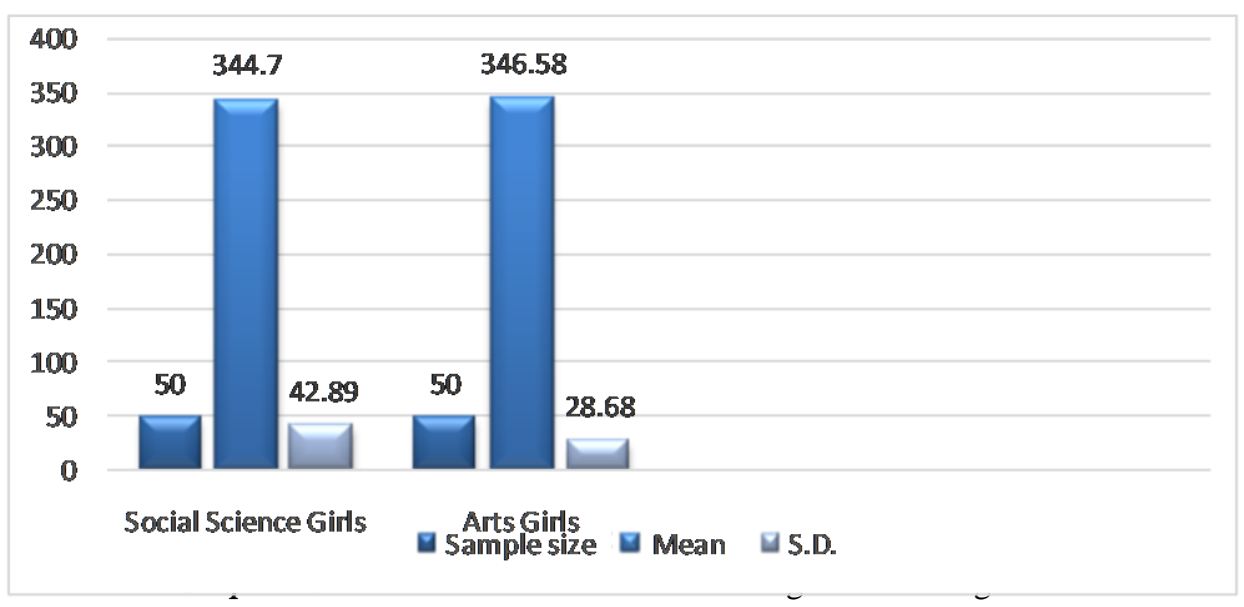

\section{Interpretation:}

It is depicted from the above table and graph that the calculated value of ' $t$ ' ( 0.797$)$ is less than the tabulated value of ' $t$ ' $(1.96 \& 2.58)$ at both the level of significance $(0.05 \& 0.01)$ respectively. So the null hypothesis is accepted and it shows that there is no significant difference in the mean scores of peace awareness between undergraduate social sciences girls and arts girls students. It further shows that arts girls have more peace awareness than the social science girls because the mean score of arts girls (346.58) is higher than the social science girls (344.7).

Objective 3: To find out the significant difference in the mean scores of peace awareness between under graduate social sciences girls and sciences girls

Hypothesis $\left(\mathrm{H}_{03}\right)$ : There will be no significance difference in the mean scores of peace awareness between undergraduate social sciences girls and science girls. 
Table 3 Statistical values of social science girls and science girls undergraduate students.

\begin{tabular}{|c|c|c|c|c|c|c|c|c|}
\hline Sample & $\mathbf{N}$ & Mean & S.D. & df & $\begin{array}{c}\mathrm{t} \text { - value } \\
\text { calculated }\end{array}$ & $\begin{array}{c}\text { Tabulated } \\
\text { t-value }\end{array}$ & L.O.S. & $\begin{array}{c}\mathbf{H}_{0} \\
(\mathbf{A} / \mathbf{R})\end{array}$ \\
\hline $\begin{array}{l}\text { Social } \\
\text { science }\end{array}$ & 50 & 344.70 & 42.89 & \multirow[t]{2}{*}{98} & \multirow[t]{2}{*}{0.834} & 1.96 & 0.01 & \multirow[t]{2}{*}{ Accepted } \\
\hline Science & 50 & 346.18 & 25.44 & & & 2.58 & 0.05 & \\
\hline
\end{tabular}

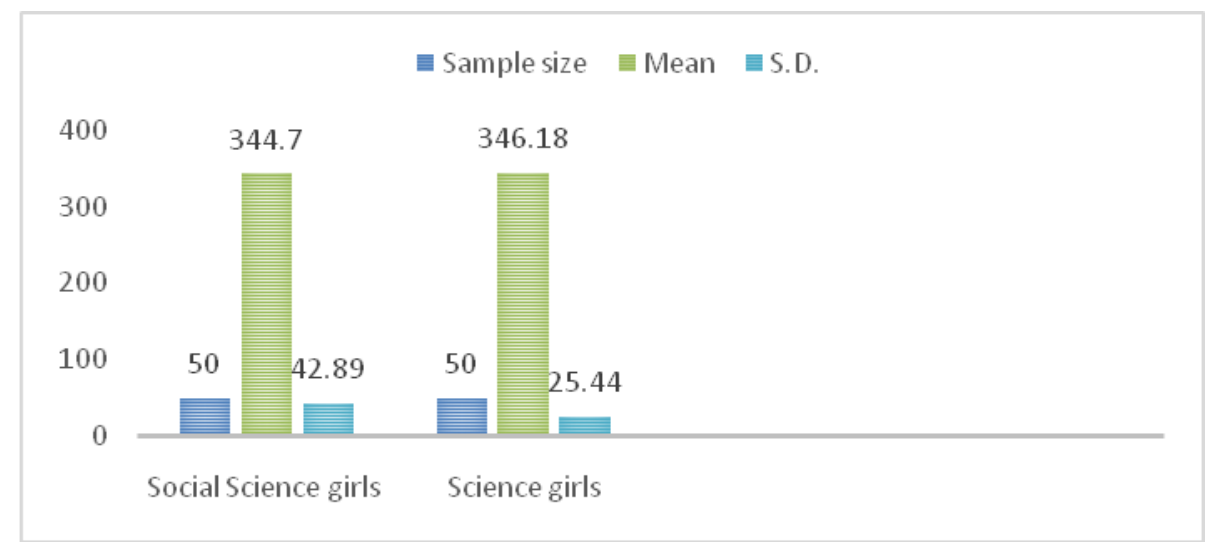

Graph 3 Statistical values of social science girls and science girls.

\section{Interpretation}

It is depicted from the above table and graph that the calculated value of ' $t$ ' $(0.834)$ is less than the tabulated value of ' $t$ ' $(1.96 \& 2.58)$ at both the level of significance $(0.05 \& 0.01)$ respectively. So the null hypothesis is accepted and it shows that there is no significant difference in the mean scores of peace awareness between undergraduate social sciences girls and science girls. It further shows that Science girls have more peace awareness than the social science girls because the mean score of science girls (346.18) is higher than the social science girls (344.70).

Objective 4: To find out the significant difference in the mean scores ofpeace awareness between under graduate arts girls and sciences girls.

Hypothesis $\left(\mathrm{H}_{04}\right)$ : There will be no significance difference in the mean scores of peace awareness between undergraduate arts girls and science girls.

Table 4 Statistical values of arts girls and science girls undergraduate students.

\begin{tabular}{|c|c|c|c|c|c|c|c|c|}
\hline Sample & $\mathbf{N}$ & Mean & S.D. & df & $\begin{array}{c}\text { t- value } \\
\text { calculated }\end{array}$ & $\begin{array}{c}\text { Tabulated } \\
\text { t-value }\end{array}$ & L.O.S. & $\begin{array}{c}\mathbf{H}_{\mathbf{0}} \\
(\mathbf{A} / \mathbf{R})\end{array}$ \\
\hline Arts girls & 50 & 346.58 & 28.68 & \multirow[t]{2}{*}{98} & \multirow[t]{2}{*}{0.941} & 1.96 & 0.01 & \multirow[t]{2}{*}{ Accepted } \\
\hline $\begin{array}{l}\text { Science } \\
\text { girls }\end{array}$ & 50 & 346.18 & 25.44 & & & 2.58 & 0.05 & \\
\hline
\end{tabular}




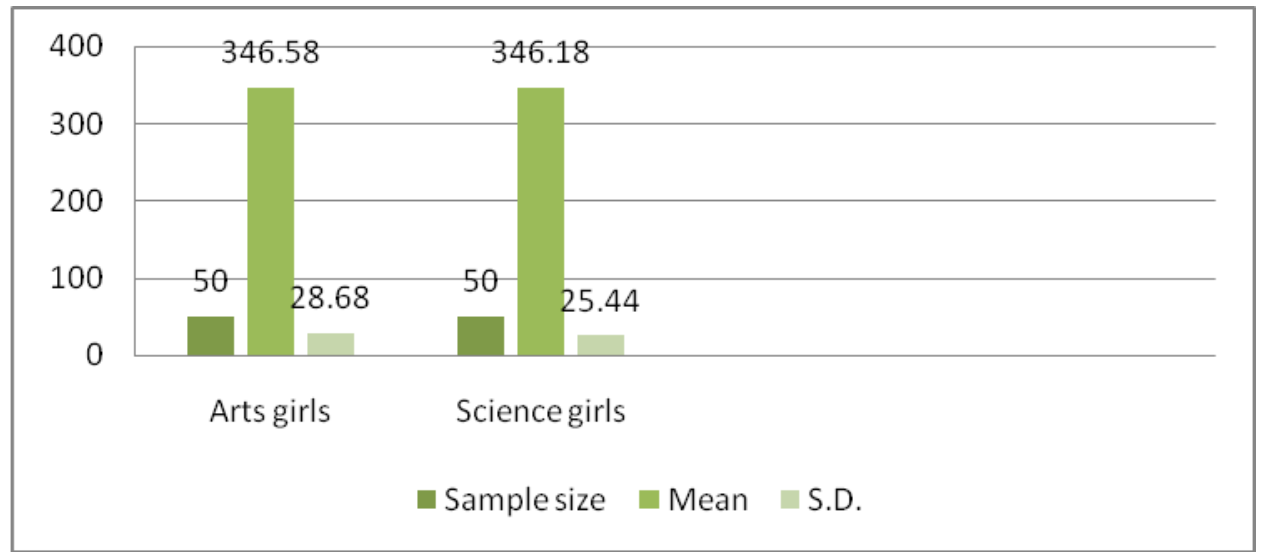

Graph 4 Statistical values of arts girls and science girls.

\section{Interpretation:}

It is depicted from the above table and graph that the calculated value of ' $t$ ' $(0.941)$ is less than the tabulated value of ' $t$ ' $(1.96 \& 2.58)$ at both the level of significance $(0.05 \& 0.01)$ respectively. So the null hypothesis is accepted and it shows that there is no significant difference in the mean scores of peace awareness between undergraduate arts girls and science girls. It further shows that arts girls and science girls have equal peace awareness because the mean score of arts girls (346.58) is relatively equal to the science girls (346.18).

Objective 5: To find out the significant difference in the mean scores ofpeace awareness between under graduate social sciences boys and arts boys.

Hypothesis $\left(\mathrm{H}_{05}\right)$ : There will be no significance difference in the mean scores of peace awareness between undergraduate social sciences boys and arts boys.

Table 5 Statistical values of social science boys and arts boys undergraduate students

\begin{tabular}{|c|c|c|c|c|c|c|c|c|}
\hline Sample & $\mathbf{N}$ & Mean & S.D. & df & $\begin{array}{c}\text { t- value } \\
\text { calculated }\end{array}$ & $\begin{array}{c}\text { Tabulated } \\
\text { t-value }\end{array}$ & L.O.S. & $\begin{array}{c}\mathbf{H}_{\mathbf{0}} \\
(\mathbf{A} / \mathbf{R})\end{array}$ \\
\cline { 1 - 7 } $\begin{array}{c}\text { Social } \\
\text { science }\end{array}$ & 50 & 349.92 & 27.33 & 98 & 0.437 & 1.96 & 0.01 & Accepted \\
\cline { 1 - 3 } Arts boys & 50 & 345.88 & 24.36 & & & 2.58 & 0.05 & \\
\hline
\end{tabular}

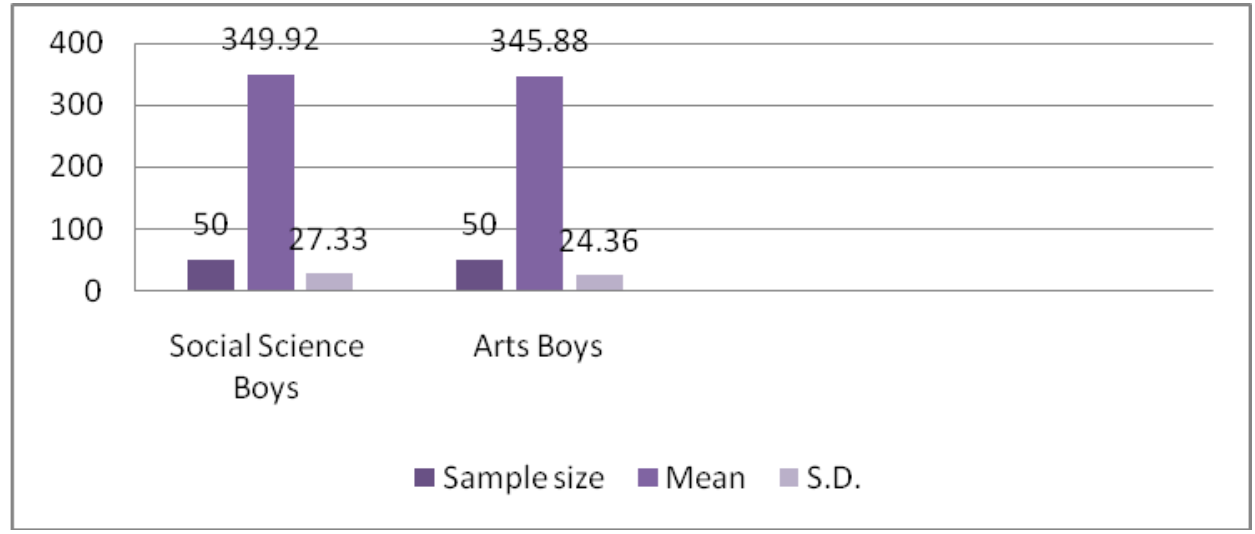

Graph 5 Statistical values of social science boys and arts boys 


\section{Interpretation:}

It is depicted from the above table and graph that the calculated value of ' $t$ ' $(0.437)$ is less than the tabulated value of ' $t$ ' $(1.96 \& 2.58)$ at both the level of significance $(0.05 \& 0.01)$ respectively. So the null hypothesis is accepted and it shows that there is no significant difference in the mean scores of peace awareness between undergraduate social sciences boys and arts boys students. It further shows that social science boys have more peace awareness than the arts boys because the mean score of social science boys (349.92) is higher than the arts boys (345.88).

Objective 6: To find out the significant difference in the mean scores of peace awareness between under graduate social sciences boys and sciences boys.

Hypothesis $\left(\mathrm{H}_{06}\right)$ : There will be no significance difference in the mean scores of peace awareness between undergraduate social sciences boys and science boys.

Table 6 Statistical values of social science boys and science boys undergraduate students.

\begin{tabular}{|c|c|c|c|c|c|c|c|c|}
\hline Sample & $\mathbf{N}$ & Mean & S.D. & df & $\begin{array}{c}\text { t- value } \\
\text { calculated }\end{array}$ & $\begin{array}{c}\text { Tabulated } \\
\text { t-value }\end{array}$ & L.O.S. & $\mathbf{H}_{\mathbf{0}}$ \\
$(\mathbf{A} / \mathbf{R})$
\end{tabular}

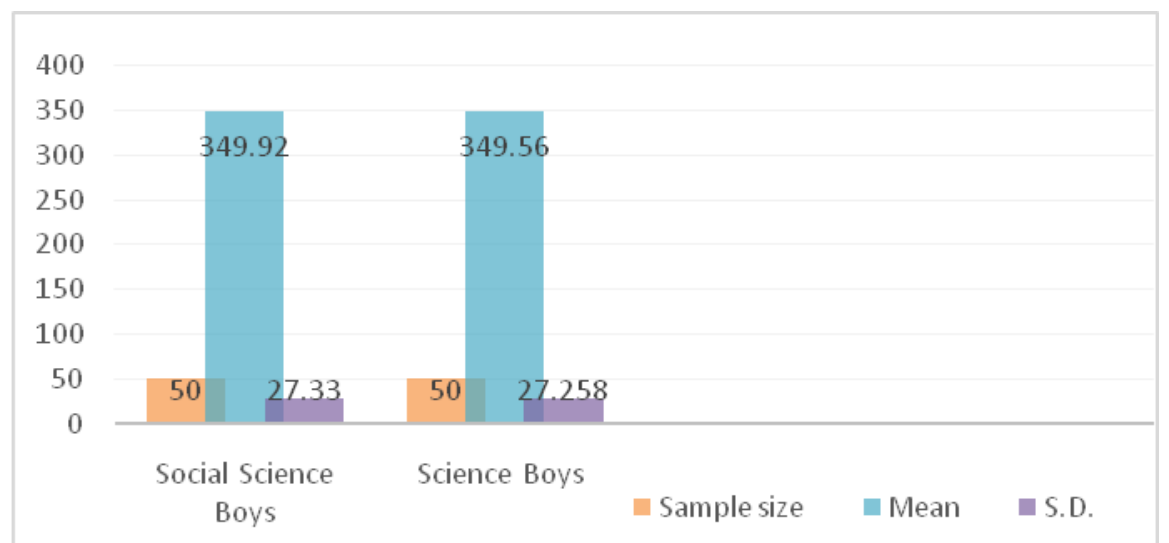

Graph 6 Statistical values of social science boys and science boys

\section{Interpretation:}

It is depicted from the above table and graph that the calculated value of ' $t$ ' $(0.948)$ is less than the tabulated value of ' $t$ ' $(1.96 \& 2.58)$ at both the level of significance $(0.05 \& 0.01)$ respectively. So the null hypothesis is accepted and it shows that there is no significant difference in the mean scores of peace awareness between undergraduate social sciences boys and arts boys students. It further shows that social science boys and arts boys have relatively equal peace awareness because the mean score of social science boys (349.92) and science boys (349.56) are relatively equal.

Objective 7: To find out the significant difference in the mean scores of peace awareness between under graduate arts boys and sciences boys.

Hypothesis $\left(\mathrm{H}_{07}\right)$ : There will be no significance difference in the mean scores of peace awareness between undergraduate arts boys and science boys. 
Table 7 Statistical values of arts boys and science boys undergraduate students.

\begin{tabular}{|c|c|c|c|c|c|c|c|c|}
\hline Sample & N & Mean & S.D. & df & $\begin{array}{c}\text { t- value } \\
\text { calculated }\end{array}$ & $\begin{array}{c}\text { Tabulated } \\
\text { t-value }\end{array}$ & L.O.S. & $\begin{array}{c}\mathbf{H}_{\mathbf{0}} \\
(\mathbf{A} / \mathbf{R})\end{array}$ \\
\cline { 1 - 3 } Arts boys & 50 & 345.88 & 24.36 & 98 & 0.478 & 1.96 & 0.01 & Accepted \\
\cline { 1 - 3 } $\begin{array}{c}\text { Science } \\
\text { boys }\end{array}$ & 50 & 349.56 & 27.25 & & & 2.58 & 0.05 & \\
\hline
\end{tabular}

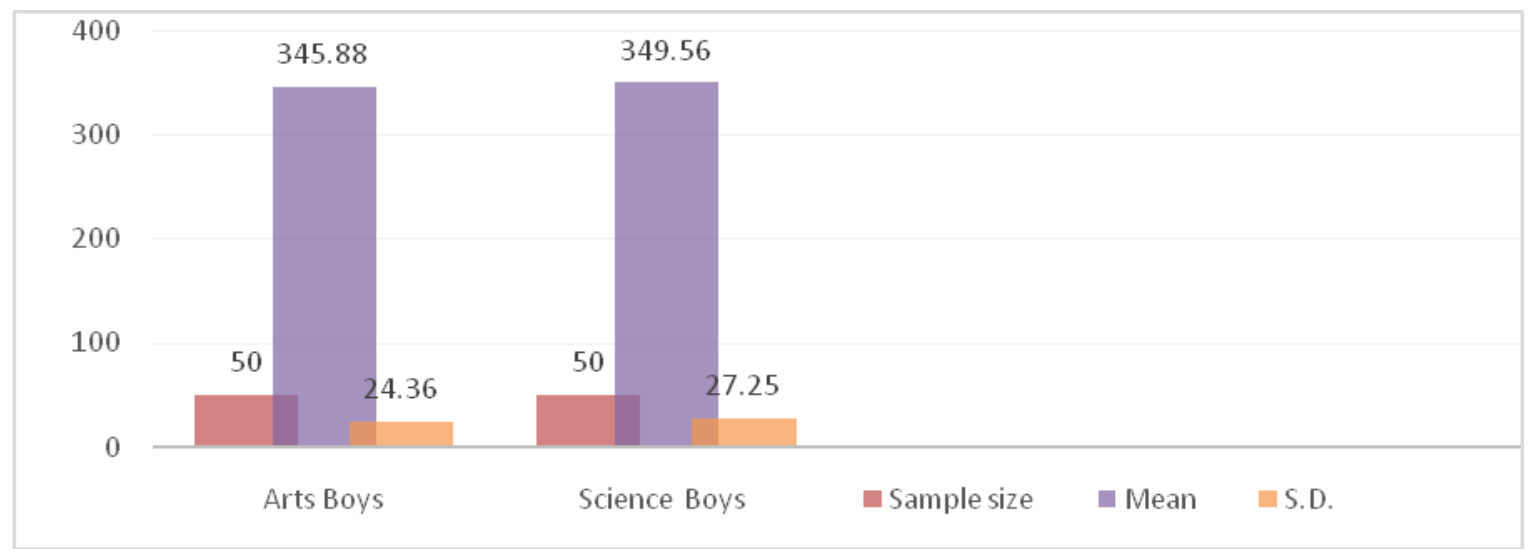

Graph 7 Statistical values of arts boys and science boys

\section{Interpretation:}

It is depicted from the above table and graph that the calculated value of ' $t$ ' $(0.478)$ is less than the tabulated value of ' $t$ ' $(1.96 \& 2.58)$ at both the level of significance $(0.05 \& 0.01)$ respectively. So the null hypothesis is accepted and it shows that there is no significant difference in the mean scores of peace awareness between undergraduate arts boys and science boys. It further shows that science boys have more peace awareness than the arts boys because the mean score of science boys (349.56) is higher than the arts boys (345.88).

\section{Discussion based on the major findings}

The research means the innovation of new ideas and opinions. The main purpose of educational research is to understand, explain, predict and control human behaviour in individual or social situations. It also brings certain ideas and suggestions to live in harmony with society and develop of inner peace.

The major findings of the study are as following:

$>$ Boys have high emotional radar but low conflict understanding; on other hand girls has low emotional radar but high conflict understanding. The reason could be that for understanding conflict; listening skills and communication skills are important aspect and girls are more patient listeners and are able to communicate effectively.

$>$ Science girls have low score in social skills, understanding conflict and emotional radar than the arts and social sciences girls. The reason can be, science girls are more academically involved and moreover it can be said that they give more time to their academic work than on their social relationship.

$>$ Arts girls have low score in inner peace dimension than compared to sciences and social sciences girls.

$>$ Human rights awareness is found to be equal in the girls of all the streams i.e. social science, arts and science.

$>$ The boys of all the streams i.e. social science, arts and science are found to be having same awareness about their inner peace. The reason is that boys find an effective way to de-stress their mind and are more spiritually aware as they have scored high on emotional radar.

$>$ Arts boys have scored low on understanding conflict and human rights than the social science and science boys.

$>$ The peace with nature awareness is found to be equal in both boys and girls in all the streams. The reason is that as environmental studies is being taught right from the school level the students are now more aware about the ethics related to the environment and their responsibilities in protecting their environment. 


\section{Educational implications}

The educational implications of the study are as follows:

- NCF 2005 has given its support on peace education as an important subject.

- UNESCO also considered peace education importance for the society.

- NCF for Teacher Education has also emphasized the importance of peace education in the teacher training programmes.

- It is very importance to know the awareness of peace among the students at all levels. The present scale will help in finding out the levels of peace awareness among undergraduate students.

- The teachers can identify the areas or dimensions in which development of peace awareness is strong and weak among the students.

- The students can also use this scale for self-assessment about their peace awareness.

- Teacher education institutes can work for development of peace culture among the students.

- Future researchers can also use this questionnaire to find the awareness level of peace in their research sample along with other variable of the studies.

\section{Suggestions}

Research can be done in any field with any sample. But due to lack of time and resources, in the present research some delimitation was encountered. For the further research purpose the following suggestions are given by the investigator:

1. The research can be conducted on a larger sample for more effective results.

2. In the present research only one variable was under study, others variables like temperament, personality factors and adjustment can be studied in relation to peace awareness.

3. The present research formulated six related dimensions of peace awareness; other related dimensions like democratic values, secularism and gender equality values can also be involved.

4. In the research, the sample was from only three faculties of Aligarh Muslim University. Other faculties like life sciences, commerce and law can also be included.

6. Aligarh Muslim University was only considered in this study, Inter university comparison can also be made to check the peace awareness among students.

7. Other levels of formal education can also be included and separate test could be constructed for school children.

8. The scale can be used in others languages by translating the language of the scale.

Thus by these suggestions we can unfold many areas in which peace awareness can be taken as a variable in the research in relation to various variables. Moreover Peace Awareness can widen its scope in multidisciplinary researches.

\section{References}

[1] Koul, L. (1999), Methodology of Educational Research, Vikas Publishing Hous Pvt. Ltd. New Delhi.

[2] Loreta N.C. and Jasmin N.G. (2008), Peace Education: A Pathway to a Culture of Peace, Miriam College Quezon City, Philippines.

[3] Mangal, S.K. (2010), Statistics in Psychology and Education, PHI Learning Pvt. Ltd., New Delhi.

[4] National Curriculum Framework (2005), NCERT, New Delhi.

[5] National Curriculum Framework for Teacher Education (2009), NCTE, New Delhi

[6] NCERT (2006), Education for Peace, Position Paper of National Focus Group, NCERT, New Delhi.

[7] Pandey, S. (Ed) (2004), Concept of Peace in 'Self-Instructional Package on Peace Education'. NCERT, New Delhi.

[8] Pant, D. and Gulati, S. (2014), Ways to peace: A resources book for teachers, NCERT, New Delhi.

[9] UN (2007), Peace Education Site Draft. 20 August 2000.

[10] UNESCO (2001), Learning the Way of Peace: A Teachers' Guide to Peace Education.

[11] UNESCO (2002), Learning to Be: A Holistic and Integrated Approach to Value Education for Human Development. UNESCO, Bangkok.

[12] UNESCO (2004), Learning to Live Together: Building Skills, Values and Attitudes for the Twenty First Century, UNESCO, New Delhi.

[13] UNESCO (2005), Peace Education: Framework for Teacher Education. UNESCO, New Delhi. 